Special Issue of the 8th International Advances in Applied Physics and Materials Science Congress (APMAS 2018)

\title{
Seismic Behavior of Some Ancient Masonry Structures in Antalya
}

\author{
P. Usta* \\ Suleyman Demirel University, Department of Civil Engineering, Isparta, Turkey
}

\begin{abstract}
Ancient masonry structures are very important to carry cultural heritage to future generations. Therefore, it is very important to protect them against disasters like earthquakes. Ancient masonry structures are particularly vulnerable to dynamic actions, especially seismic actions. Antalya is located in a moderately seismic zone. Many earthquakes have occurred in this city in the last few decades. In this paper, three ancient historical masonry structures have been selected, which are located in different districts of Antalya. The selected structures were constructed of similar geometry. Structures were modeled by using the finite element software, SAP2000. Time history analyses were carried out using 10 real ground motion data on the models. Displacements and stress values were interpreted, and the results were displayed graphically and discussed.
\end{abstract}

DOI: 10.12693/APhysPolA.135.575

PACS/topics: finite element methods, earthquakes, seismicity, residential and commercial buildings, modeling and analysis

\section{Introduction}

Earthquakes are very common in different parts of the world. Geographical statics of Turkey shows that almost all part of the land is vulnerable to earthquakes. Due to these earthquakes, large destruction is caused to the infrastructures and the structures. The structures, which appeared to be strong enough, may crumble like houses of cards during earthquake and deficiencies may be exposed [1]. The seismic assessment of historical masonry structures is a complex task because the global behavior of these kind of structures depends on various factors, as the behavior of the single walls, the connections between them, the typology and stiffness of the floor (flexible or rigid diaphragms), and the strong nonlinearities of the material [2-5].

Different models for the assessment of masonry structures exist in the literature: they are both one-dimensional (frame or macro-element) and twodimensional (finite elements) [5]. The paper focused on the three ancient masonry structures, which were constructed many years ago. Some parts of these structures have partial damages and some parts of them survived without substantial damages. Masonry structures are especially vulnerable to seismic risk unless they are constructed with special consideration of seismic design. These structures are extensively being used and occupied by families. Almost all masonry structures were constructed by using best available material during the time of construction with best available technology. Nevertheless, seismic resistance of them is intrinsically limited. The reasons for this are: there was no available code at that time and no advanced materials such as concrete and steel were available. It is assumed that

\footnotetext{
* corresponding author
}

these structures were built based on traditional knowledge and technology [6]. A finite element analysis is carried out in order to assess earthquake seismicity of the ancient masonry structure. A finite element software SAP2000 was used for the analysis. It is found that some parts of the existing forms of the structures are reliable, however some parts are highly vulnerable to the future.

\section{Structural analysis stage: ancient masonry structures}

This study focuses on three ancient masonry structures, which are located in the same area in Antalya. Those characteristics are quite similar [7]. For this study, the thick masonry walls were modeled with an eightnodded solid element of SAP2000. The roofs were modeled with shell element. It is not realistic to use detailed models of walls and connections in large scale analysis, because of the geometric and material properties of the constituents/economy constraints [1]. For most large-scale analysis, it is acceptable to model both regular masonry and rubble masonry walls assuming a continuum homogeneous material. The internal composite walls, the roofs, and other architectural parts associated with the structures were considered in the modeling. The foundation of the structure was fully restrained. The real earthquake record loads associated with these elements were included in the analysis. The whole structures were taken for modeling. The $3 \mathrm{D}$ homogeneous solid element model of the modeled structures are shown in Fig. 1.

Figure 1 shows a 3D view of ancient masonry structures. Table I gives the material properties used in the dynamic analysis of this paper. These properties are chosen based on a literature review. 

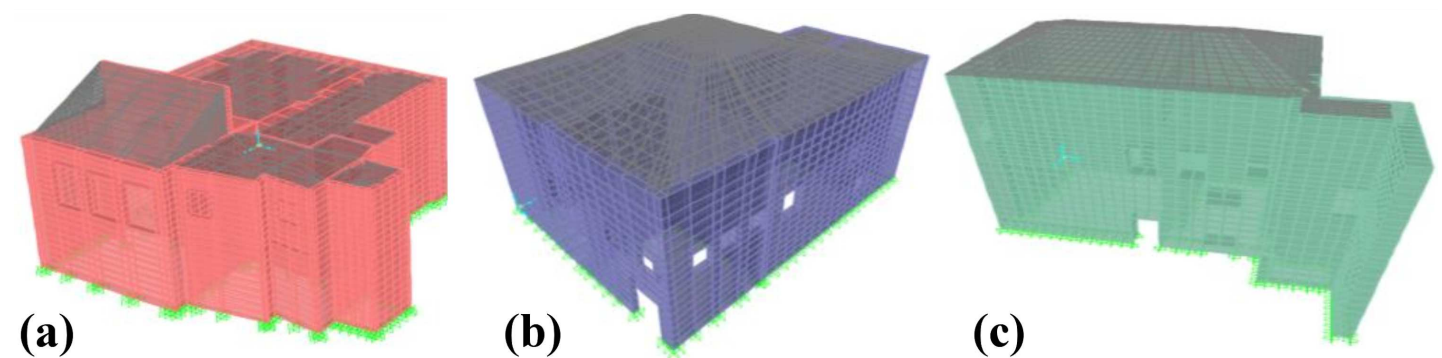

Fig. 1. 3D view of ancient masonry structures: (a) Ahmet Sen House, (b) Katri Gonullu House, (c) Rifat Kuleli House.

TABLE I

Material properties used in the modeling.

\begin{tabular}{l|c|c|c}
\hline \hline & $\begin{array}{c}\text { Modulus } \\
\text { of elasticity } \\
{\left[\mathrm{N} / \mathrm{m}^{2}\right]}\end{array}$ & $\begin{array}{c}\text { Poisson } \\
\text { ratio }\end{array}$ & $\begin{array}{c}\text { Density } \\
{\left[\mathrm{kg} \mathrm{m}^{-} 3\right]}\end{array}$ \\
\hline stone walls & $2.333 \times 10^{10}$ & 0.2 & 2500 \\
covered materials & $1.300 \times 10^{10}$ & 0.16 & 2243
\end{tabular}

\section{The analysis of results for ancient masonry houses}

The structural analysis of the masonry structures were conducted according to the linear time history analysis by using 10 ground motion records. As a result of the analysis, different parameters studied such as tensile/strain
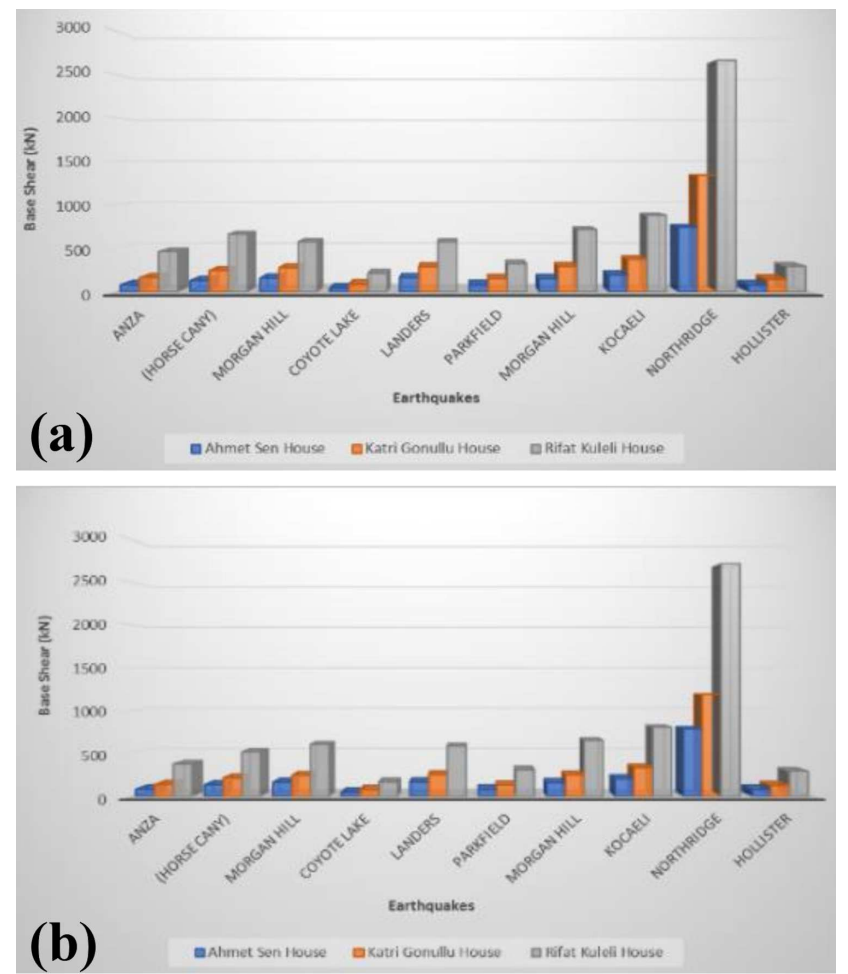

Fig. 2. Maximum base shear of the ancient masonry structures under earthquake load in the $x$ and $y$-direction.
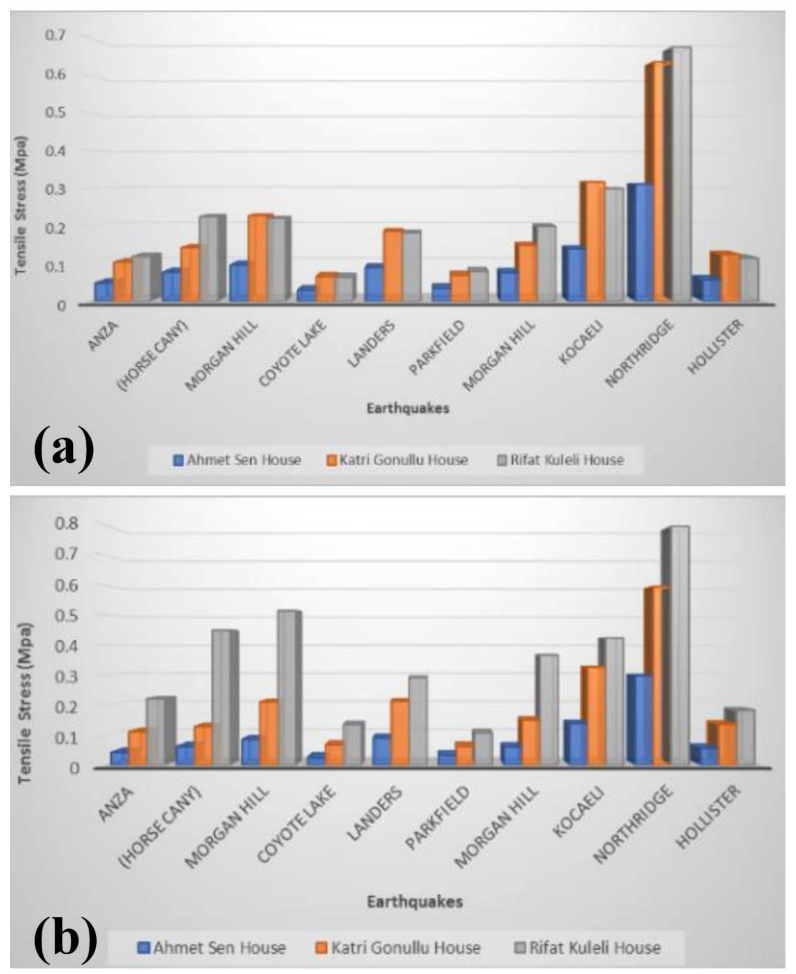

Fig. 3. Maximum tensile stress of the ancient masonry structures under earthquake load in the $x$ and $y$-direction.

stress, base shear, and displacement values were determined, and these values were compared. The results of tensile/strain stress, base shear, and displacement are shown in Figs. 2-4, respectively, All the solid elements were assumed to have the same properties to determine structural behavior of masonry structures.

\section{Conclusion}

In the present paper, a numerical assessment of the earthquake hazards for masonry structures in Antalya, Alanya has been carried out under self-weight and earthquake loads. The numerical assessment has been conducted by performing linear static analyses using the commercial codes, namely SAP2000.

The utilization of commercial software, despite the approximations introduced in the material models adopted for masonry, is necessary to maintain the 

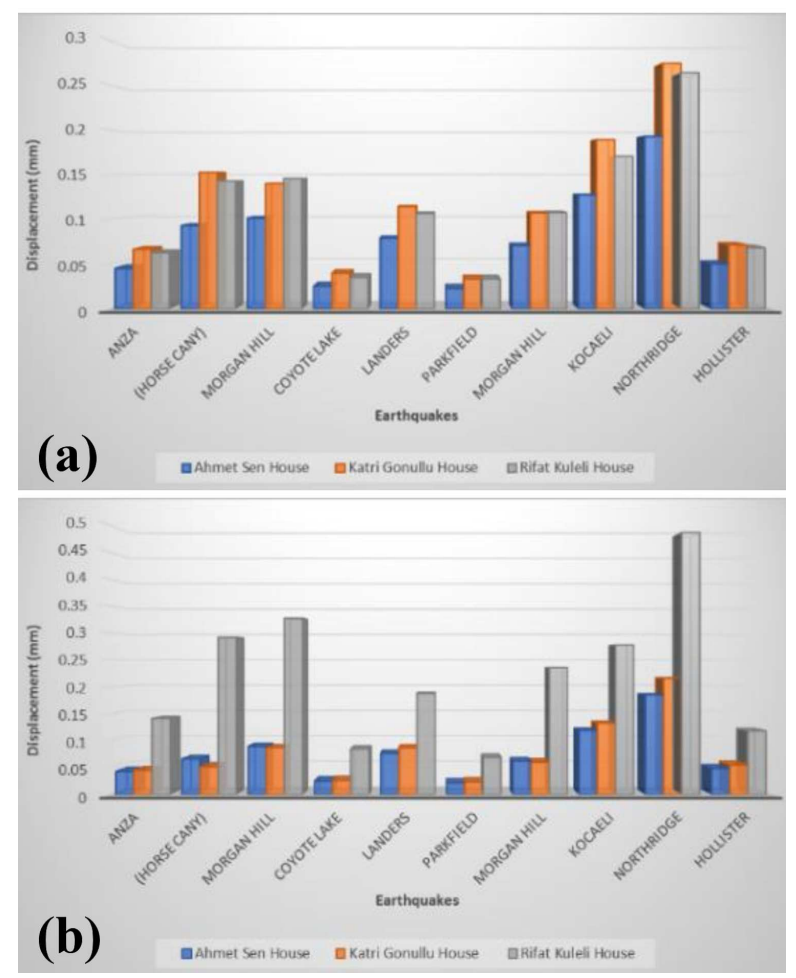

Fig. 4. Maximum displacements of the ancient masonry structures under earthquake load in the $x$ and $y$-direction.

approach available to the majority of practitioners involved in the standard design. The chosen structures have a clear structural scheme and they are composed of several elements representing varied materials and historical constructive techniques. The allowable tensile stresses are exceeded only at the corners of the openings and at the bottom corners of the walls in small patches. The time history analysis results show that stress values are not exceeded at the load bearing members of three masonry structures.
The allowable tensile stresses are exceeded only at the corners of the openings and at the bottom corners of the walls in small points. It results in the fact that the walls are safe and do not require any strengthening or repair action. The structures are still being used. Therefore, some small problems can occur in the future, which naturally appears during the service life of every structure.

For the three masonry structures, the highest stresses elements appear at the door and window spaces and the bottom walls. Evaluation of historical masonry structures was important for cultural heritage and transferring them to the future. It is very important to protect them by taking measures from the structural aspect. In order to transfer cultural heritage to the next generations, we need to know the structural properties of these structures.

\section{References}

[1] P. Kumar, G. Vani, Int. J. Eng. Sci. 6, 255 (2016).

[2] B. Calderoni, A. Ghersi, P. Lenza, in: Proc. 10th Int. Brick and Block Masonry Conf., Calgary (Canada) 1994, p. 227.

[3] P. Lenza, in: Proc. 11th World Conf. on Earthquake Engineering, Acapulco 1996.

[4] T.E. Boothby, H.S. Atamtürktür, E. Erdogmus, Manual for the Assessment of Load-Bearing Unreinforced Masonry Structures, Report for the US Department of the Interior, 2006.

[5] F. Bucchi, S. Arangio, F. Bontempi, in: Proc. 14th Int. Conf. on Civil, Structural and Environmental Engineering Computing, Sardinia (Italy) 2013 Vol. 36.

[6] S.S. Khadka, Kathmandu Univ. J. Sci. Technol. 9 , 15 (2013).

[7] M. Kapancı, M.Sc. Thesis, Selcuk University, Konya 2008. 